Museum of English Rural Life, Whiteknights Park, Reading. This, probably unique, collection of log hives, skeps of various materials and patterns, hackles, old style wooden hives of various kinds, honey and wax extractors, drone traps, feeders, smokers, queen excluders, etc., has been collected during the past few years by the Bee Research Association and is on permanent loan to the Museum. Entrance is free and a useful descriptive catalogue can be obtained from the Museum.

\section{International Conference on Fishery Statistics}

AN international meeting of experts on fishery statistics in the North Atlantic area is to be held in Edinburgh during September 22-30. The conference is being convened by the Food and Agriculture Organization of the United Nations in co-operation with the International Commission for the North West Atlantic Fisheries and the International Council for the Exploration of the Sea. Governments concerned with the North Atlantic fisheries have been invited to nominate experts directly concerned with collecting, analysing and publishing statisties on the fishing industries and trades of their countries, and the Scottish Home Department will act as hosts to the delegates. It is hoped that delegates will be able to identify the main difficulties encountered in providing statistical data for the use of Governments, international agencies and the fishing industry, and will indicate the action to be taken to eliminate or reduce such difficulties.

\section{The Marine Biological Association of India}

The Marine Biological Association of India was founded at Mandapam Camp, to promote interest in marine biological and cognate sciences. The Association was formally inaugurated by the Hon. Mrs. Lourdhammal Simon, Minister for Fisheries and Local Administration, Madras State, on January 3. The following officers were elected: Dr. S. Jones (president), Prof. R. V. Seshaiya (vice-president), Dr. R. Raghu Prasad and Dr. C. P. Gnanamuthu (secretaries), Dr. R. P. Varma (assistant secretary), Shri K. V. Rao (treasurer), Dr. P. N. Ganapati (editor), Dr. R. Subrahmanyan (joint editor), and Dr. S. V. Job (managing editor). The official organ of the Association, the Journal of the Marine Biological Association of India, is expected to be issued half-yearly. Membership is open to all who are interested. All correspondence should be addressed to the Secretary, Marine Biological Association of India, Marine Fisheries P.O., Mandapam Camp, South India.

\section{University News :}

North Staffordshire

THE following appointments, among others, have been made : Mr. E. M. Hugh-Jones, fellow and tutor of Keble College, Oxford, professor of economics, in succession to Prof. B. R. Williams; Miss A. Eden, senior lecturer in education, Homerton College, Cambridge, lecturer in education and women's warden; Dr. V. C. Ewing, pressed steel research fellow, University of Oxford, lecturer in chemistry ; M. F. Newman assistant lecturer in mathematics.

\section{Announcements}

AN international conference on High Energy Accelerators and Instrumentation will be held at, CERN during September 14-19. Further information can be obtained from the Conference Secretariat, CERN, Geneva 23, Switzerland.
THE thirteenth congress of the International Scientific Film Association is to be held in London and Oxford during September 23-October 2, under the auspices of the British Scientific Film Association. Further particulars can be obtained from the Association's office at 3 Belgrave Square, London, S.W.1.

The International Council for Building Research, Studies and Documentation is organizing an international congress, to be held in Rotterdam during September 21-25. The topies for discussion include the design and calculation of structures; research problems relating to the application of heavy concrete elements; and fundamental aspects of the transmission of knowledge. Further information can be obtained from the C.I.B. Secretariat, c/o Bouwcentrum, P.O. Box 299, Rotterdam.

THE Dublin and District Section of the Society of Chemical Industry, in conjunction with the Agriculture Group of the Society, is to hold a symposium in Dublin during September 15-18. The subject will be "Chemical Aspects of the Production and Use of Grass", and it is intended that the meeting shall include the presentation and discussion of pre-printed papers, and lectures and visits to places of scientific interest. Further information can be obtained from the honorary secretary, R. O. V. Lloyd, Chemist's Laboratory, A. Guinness Son and Co. (Dublin), Ltd., St. James's Gate, Dublin.

THE Electrical Engineering Department of the University of Birmingham is arranging two informal residential conferences in September 1959. The first, on dielectric devices, will be held during September 14-17, and the second, on modern network theory, during September 21-24. Preliminary programmes of papers and discussions have already been arranged. Further information can be obtained from the Secretary of the Electrical Engineering Department, The University, Birmingham 15. In order to preserve the informal nature of the conferenees, numbers will have to be strictly limited.

THE fourth annual conference of the British Society for the Philosophy of Science will be held at Newnham College, Cambridge, during September 25-27, when the following papers will be read: "Scientific Research and the Philosophy of Science", by Prof. H. Dingle and Prof. H. C. Longuet-Higgins; "Classification, Concept-formation, and Language" by Miss M. Masterman and Dr. A. Koslow; "Knowing and Being", by Prof. M. Polanyi and Prof. R. B. Braithwaite; "Biology and Physics", by Prof. J. H. Woodger and Dr. E. H. Hutten. Further information can be obtained from the honorary secretary of the Society, Miss M. B. Hesse, University College, London, W.C.I.

The first Congrès International de Prophylaxie Criminelle will be held in Paris during September 27-30. Further information can be obtained from M. Stanciu, 7 Avenue Général Leclercq, Boulogne sur Seine.

Erratum. In the communication entitled "Possible Causes of Geomagnetic Fluctuations having a 6-Sec. Period", by H. J. Duffus, J. A. Shand and Sir Charles Wright, published in Nature of May 23, p. 1479, the caption for Fig. 3 should conclude: " . . . and of $\delta \bar{X} / \delta t$ taken at Borrego, California, U.S.A.". The reference in the text to Fig. 3 should read: "Fig. 3 shows the simultaneous records of $\delta Y / \delta t$ at our base station and of $\delta X / \delta t$ near Borrego Springs ...". 